\title{
Front Matter: Volume 11055
}

, "Front Matter: Volume 11055," Proc. SPIE 11055, XII Conference on Reconnaissance and Electronic Warfare Systems, 1105501 (27 March 2019); doi: $10.1117 / 12.2534680$

SPIE Event: XII Conference on Reconnaissance and Electronic Warfare Systems, SPIE. 2018, Oltarzew, Poland 


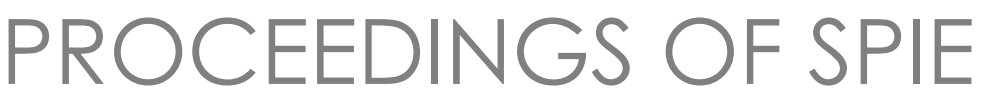

\title{
XII Conference on Reconnaissance and Electronic Warfare Systems
}

\author{
Piotr Kaniewski \\ Editor
}

19-21 November 2018

Ołtarzew, Poland

Organized by

Military University of Technology (Poland)

Sponsored by

General Staff of the Polish Armed Forces (Poland)

Electronics and Telecommunications Committee of the Polish Academy of Sciences (Poland)

Published by

SPIE 
The papers in this volume were part of the technical conference cited on the cover and title page. Papers were selected and subject to review by the editors and conference program committee. Some conference presentations may not be available for publication. Additional papers and presentation recordings may be available online in the SPIE Digital Library at SPIEDigitalLibrary.org.

The papers reflect the work and thoughts of the authors and are published herein as submitted. The publisher is not responsible for the validity of the information or for any outcomes resulting from reliance thereon.

Please use the following format to cite material from these proceedings:

Author(s), "Title of Paper," in XII Conference on Reconnaissance and Electronic Warfare Systems, edited by Piotr Kaniewski, Proceedings of SPIE Vol. 11055 (SPIE, Bellingham, WA, 2019) Seven-digit Article CID Number.

ISSN: 0277-786X

ISSN: 1996-756X (electronic)

ISBN: 9781510627857

ISBN: 9781510627864 (electronic)

Published by

SPIE

P.O. Box 10, Bellingham, Washington 98227-0010 USA

Telephone +1 3606763290 (Pacific Time) · Fax +1 3606471445

SPIE.org

Copyright @ 2019, Society of Photo-Optical Instrumentation Engineers.

Copying of material in this book for internal or personal use, or for the internal or personal use of specific clients, beyond the fair use provisions granted by the U.S. Copyright Law is authorized by SPIE subject to payment of copying fees. The Transactional Reporting Service base fee for this volume is $\$ 18.00$ per article (or portion thereof), which should be paid directly to the Copyright Clearance Center (CCC), 222 Rosewood Drive, Danvers, MA 01923. Payment may also be made electronically through CCC Online at copyright.com. Other copying for republication, resale, advertising or promotion, or any form of systematic or multiple reproduction of any material in this book is prohibited except with permission in writing from the publisher. The CCC fee code is 0277$786 \mathrm{X} / 19 / \$ 18.00$.

Printed in the United States of America.

Publication of record for individual papers is online in the SPIE Digital Library.

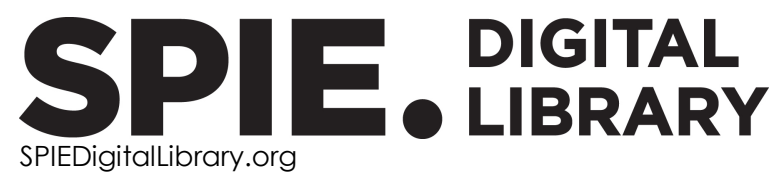

Paper Numbering: Proceedings of SPIE follow an e-First publication model. A unique citation identifier (CID) number is assigned to each article at the time of publication. Utilization of CIDs allows articles to be fully citable as soon as they are published online, and connects the same identifier to all online and print versions of the publication. SPIE uses a seven-digit CID article numbering system structured as follows:

- The first five digits correspond to the SPIE volume number.

- The last two digits indicate publication order within the volume using a Base 36 numbering system employing both numerals and letters. These two-number sets start with 00, 01, 02, 03, 04, 05, 06, 07, 08, 09, OA, OB ... 0Z, followed by 10-1Z, 20-2Z, etc. The CID Number appears on each page of the manuscript. 


\title{
Contents
}

\author{
vii $\quad$ Authors \\ ix Conference Committee \\ xiii Introduction
}

XII CONFERENCE ON RECONNAISSANCE AND ELECTRONIC WARFARE SYSTEMS

1105502 Onboard image recorder simulator for analysis of operation of vision-based navigation system [11055-1]

1105503 Semi-insulating GaP as a material for manufacturing photoconductive semiconductor switches [1 1055-2]

$1105504 \quad$ Echoes cancellation in hydroacoustic channel: experimental research [1 1055-3]

$1105505 \quad$ Parameters of quality of radar terrain images [1 1055-4]

1105506 Optical-radio hybrid technology in military wireless communication systems [11055-5]

1105507 Application of dynamic games with incomplete information to optimisation of performance of military radio networks (jamming avoidance) [11055-6]

1105508 Synchronization methods in mobile wireless links based on OFDM modulation technique [11055-7]

$1105509 \quad$ Koshelev antenna as an element of the antenna array [11055-8]

11055 OA Instantaneous frequency estimation for radar NLFM signal using combined STFT and TFD ridge smoothing technique [1 1055-9]

11055 OB Continuous wave ground penetrating radars: state of the art [1 1055-10]

11055 OC Method of radiolocation object shield zone calculation for ground jammer stations [11055-11]

11055 OD Recognition of electromagnetic sources with the use of deep neural networks [1 1055-12]

11055 OE Assessment of voice call quality in SCIP encrypted traffic [1 1055-13]

11055 OF Smoke detection in a digital image with the use of convolutional network [1 1055-14] 
11055 OG Mechanisms of immunization of broadband radio stations for targeted interference [11055-15]

$11055 \mathrm{OH} \quad$ Testing of the detector based on the Faraday effect for the detection of high-power electromagnetic pulses [11055-16]

$11055 \mathrm{Ol} \quad$ Selected properties and parameters of radio channel impulse response estimation in ISM 2.4-GHz band [1 1055-17]

$110550 \mathrm{~J} \quad$ Verification of the criterion and measures of interferences used in radio planning systems [11055-18]

11055 OK The assessment of efficiency of the automatic speaker recognition system for voices registered using a throat microphone [1 1055-20]

$11055 \mathrm{OL} \quad$ The efficiency evaluation concept of the HF jamming based on propagation prediction model ITU-R P.533 [11055-21]

11055 OM Electronic warfare systems supporting the database of the Radio Environment Maps [1 1055-22]

11055 ON Synchronous surge generator: source of ultra-high power pulses [1 1055-23]

1105500 Properties of the monopulse direction finding of microwave sources in an environment with many emitters [1 1055-25]

11055 OP A concept of a microwave seeker designed for an anti-radiation missile [1 1055-26]

$110550 Q \quad$ Prospects of simultaneous localization and mapping algorithms application in imagery intelligence [1 1055-27]

11055 OR Secure voice transmission in the coalitional communication [11055-28]

11055 OS Removal of conflicts in fusion of identification information from ELINT-ESM sensors [11055-29]

11055 OT PSO algorithm for UAV autonomous path planning with threat and energy cost optimization [1 1055-30]

11055 OU The algorithm for computation of the time difference of arrival for a secure zone monitoring system [11055-31]

11055 OV Comparison of two classifiers based on neural networks and the DTW method of comparing time series to recognize maritime objects upon FLIR images [1 1055-32]

11055 OW Analysis of estimation algorithms for electromagnetic source localization [1 1055-33]

11055 0X Processing output voltages of a single-function microwave frequency detector [1 1055-34]

11055 OY Tracking of land vehicle motion with the use of distance measurements [1 1055-35]

$110550 Z$ Application of fusion of two classifiers based on principal component analysis method and time series comparison to recognize maritime objects upon FLIR images [1 1055-36] 
1105510 Use of cognitive radio in electromagnetic warfare [1 1055-38]

1105511 The use of shunt-stubs for impedance matching improvement in planar antenna arrays [1 1055-39]

1105512 Analysis of imagery interpretability of open sources radar satellite imagery [1 1055-41]

1105513 Evaluation of the interpretability of satellite imagery obtained from open sources of information [11055-44]

$1105514 \quad$ Will WPA3 really provide Wi-Fi security at a higher level? [1 1055-45]

1105515 Verification of the results of numerical simulations of a high power pulsed L-band magnetron in experimental conditions [11055-47]

$1105516 \quad$ Method of synthesis of signal-code constructions for secretive noise-proof data transmission radio systems [1 1055-49]

1105517 Traffic congestion detection algorithm for a radar freeway monitoring system [11055-50]

1105518 The diagnostics and repair of contemporary Electronic Warfare systems [1 1055-51]

1105519 Radar air picture simulator for military radars [1 1055-52]

$110551 \mathrm{~A} \quad$ IEEE 802.11ax: giant leap in WLAN evolution [1 1055-53]

11055 1B Frequency resources sharing in FH radio networks [1 1055-54]

$110551 \mathrm{C}$ Detection, direction finding and localization of selected radio emissions with swarm technology [1 1055-55]

11055 1D Detection of complex impulse stochastic signals on the background of quasi-periodic deterministic interferences [1 1055-56]

$110551 \mathrm{E} \quad$ Analysis of main beam adaptive beamforming effect on accuracy of monopulse angle estimation in jammed environment [1 1055-58]

$110551 \mathrm{~F} \quad$ Analysis of using a MicroBlaze processor for hardware implementation of algorithms for data processing in electronic recognition devices and systems based on the example of a XILINX FPGA system [1 1055-59]

$110551 \mathrm{G} \quad$ Location errors of directional emitters in AOA system for non-line-of-sight conditions [1 1055-60]

$110551 \mathrm{H} \quad$ SDN implementation in regard to network elements security [11055-67]

$1105511 \quad$ The idea of hidden data layer in software defined network [1 1055-68] 
Proc. of SPIE Vol. 11055 1105501-6 Downloaded From: https://www.spiedigitallibrary.org/conference-proceedings-of-spie on 26 Apr 2023
Terms of Use: https://www.spiedigitallibrary.org/terms-of-use 


\section{Authors}

Numbers in the index correspond to the last two digits of the seven-digit citation identifier (CID) article numbering system used in Proceedings of SPIE. The first five digits reflect the volume number. Base 36 numbering is employed for the last two digits and indicates the order of articles within the volume. Numbers start with 00, 01, 02, 03, 04, 05, 06, 07, 08, 09, 0A, OB...0Z, followed by 10-12, 20-2Z, etc.

Baczewski, Dariusz, 14 Bednarczyk, Mariusz, 13, 19 Berlinska, Natalia, 11

Białek, R., OG

Bielecki, Z., 05

Błażejewicz, Mariusz, 14

Bugaj, Jarosław, OV Czapiewska, Agnieszka, $\mathrm{OH}$

Czopik, Grzegorz, OT, OX

Dobrowolski, A. P., OJ

Fabirovskyy, Sergiy, 1C

Fryskowska, Anna, 11

Golan, Edward, OL, 17

Gorka, Marcin, 11, 12

Górny, Kamil, OV

Graqdzki, Piotr, 1A, 1B

Grochowina, Bogusław, 05, OK

Grzywacz, Wojciech, 01

Jakubowski, Jacek, OE

Kaczmarek, Paweł, OA, 1D

Kamiński, K., OJ

Kamiński, P., 02

Kaniewski, Paweł, 06, 0L, 17

Kaniewski, Piotr, 01, OP, 15

Kawalec, Adam M., 09, 00, 18

Kedzierski, Michał, 11, 12

Kelner, Jan M., IF

Konatowski, Stanisław, OS, 15

Kosmowski, Krzysztof, Ol

Kozłowski, R., 02

Kraszewski, Tomasz, OX

Kuchta, M., OG

Kustra, Mateusz, 06, OK

Labowski, Michal, 04

Laskowski, Dariusz, OD, OF, 0Q, 14

Leśnik, Czesław, OT, 16

Łopatka, Jerzy, 07, 0Z

Lubkowski, Piotr, OD, OF, OQ

Majda-Zdancewicz, E., 02

Majewski, Paweł, 14

Małecki, J., 08

Matuszewski, Jan, OB, OC

Matyszkiel, Robert, 05, 06, OF, Ol, OK

Mikolajczyk, J., 05

Milczarek, H., 09

Milewski, Jarosław, 1A, 1B

Mirowska, A., 02

Miskiv, Volodymyr-Myron, 15

Mucha, Filip, IF
Nichoha, Vitalij, 1C

Okoń-Fq̨ara, Marta, 18

Pasternak, Mateusz, OA

Pawłowski, Piotr, OS

Paziewski, P., 02

Pers, Tomasz, $1 \mathrm{G}$

Pietkiewicz, Tadeusz, OR, OU, OY

Pietrow, Dymitr, OC

Piotrowski, Zbigniew, 13, 1G, 1H

Piwowarski, K., 02

Polak, Rafał, OD, OF, OQ

Prudyus, Ivan, 15, 1C

Przyborowski, Włodzimierz, OM

Puchlik, Marcin, 07

Rećko, Czesław, OW

Rogala, Tomasz, 16

Romanik, Janusz, OL, 17

Różycki, Andrzej, 14

Rutkowski, Adam, 0N, 00, 0W

Rychlewski, Michał, 14

Ścibiorek, Przemysław, $1 \mathrm{H}$

Sekrecka, Aleksandra, 12

Serafin, Piotr, OT, 16, 1D

Sierzputowski, Robert, OD, OQ

Sikorska-Łukasiewicz, Katarzyna, ou

Slesicki, Blazej, 10

Słowak, Pawel, OP

Slowik, Adam, 10

Solarczyk, Maciej, OE

Stec, Bronisław, OW

Studanski, Ryszard, 03, $\mathrm{OH}$

Suchanski, Marek, OL

Suproniuk, M., 02

Szabra, D., 05

Szkop, Emil, 14

Szmit, Grzegorz, $0 Z$

Tatoń, R., 0J

Teodorczyk, M., 02

Urban, Robert, 1A, 1B

Vashchyshyn, Liubomyr, 1C

Wajszczyk, Bronisław, $1 \mathrm{E}$

Walczykowski, Piotr, 12

Walkowiak, M., 08

Walkowiak, Marcin, 12

Wierzbicki, Damian, 11

Wierzbowski, M., 02

Wilgucki, Kamil, 1A, 1B

Wiśnios, Michał, OE

Wiszniewska-Matyszkiel, Agnieszka, 06 
Witczak, Andrzej, 18

Witenberg, A., 08

Wojtyra, Damian, $\mathrm{OQ}$

Woźniak, Martyna, 14

Zak, Andrzej, 03

Ziółkowski, Cezary, $1 \mathrm{~F}$

Zubel, Krzysztof, OL, 17

Proc. of SPIE Vol. 11055 1105501-8

Downloaded From: https://www.spiedigitallibrary.org/conference-proceedings-of-spie on 26 Apr 2023 Terms of Use: https://www.spiedigitallibrary.org/terms-of-use 


\title{
Conference Committee
}

\author{
Conference Chair \\ Piotr Kaniewski, Military University of Technology (Poland) \\ Deputy Conference Chair
}

Zbigniew Piotrowski, Military University of Technology (Poland)

Secretary

Stanisław Konatowski, Military University of Technology (Poland)

Program Committee

Marek Amanowicz, Military University of Technology (Poland) Zbigniew Bielecki, Military University of Technology (Poland) Jacek Borkowski, Military Institute of Armament Technology (Poland) Witold Czarnecki, Military University of Technology (Poland) Andrzej P. Dobrowolski, Military University of Technology (Poland) Andrzej Felski, Polish Naval Academy (Poland) Janusz Furtak, Military University of Technology (Poland) Piotr Gajewski, Military University of Technology (Poland) Jacek Jakubowski, Military University of Technology (Poland) Piotr Kaniewski, Military University of Technology (Poland) Ryszard J. Katulski, Gdansk University of Technology (Poland) Adam Kawalec, Military University of Technology (Poland) Michał Kędzierski, Military University of Technology (Poland) Stanisław Konatowski, Military University of Technology (Poland) Krzysztof Kopczyński, Military University of Technology (Poland) Roman Kubacki, Military University of Technology (Poland) Krzysztof Kulpa, Warsaw University of Technology (Poland) Dariusz Laskowski, Military University of Technology (Poland) Jerzy Kopatka, Military University of Technology (Poland) Henryk Madura, Military University of Technology (Poland) Jerzy Miłosz, PIT-RADWAR (Poland) Józef Modelski, Warsaw University of Technology (Poland) Mateusz Pasternak, Military University of Technology (Poland) Jerzy Pietrasiński, Military University of Technology (Poland) Zbigniew Piotrowski, Military University of Technology (Poland) Ryszard Romaniuk, Warsaw University of Technology (Poland) Piotr Samczyński, Warsaw University of Technology (Poland) Bogusław Smólski, Military University of Technology (Poland) Bronisław Stec, Military University of Technology (Poland) 
Marek Suchański, Military Communications Institute (Poland)

Waldemar Susek, Military University of Technology (Poland)

Zenon Szczepaniak, Military University of Technology (Poland)

Zbigniew Watral, Military University of Technology (Poland)

Marian Wnuk, Military University of Technology (Poland)

Józef Woźniak, Gdansk University of Technology (Poland)

Krzysztof Zaremba, Warsaw University of Technology (Poland)

Zbigniew Zieliński, Military University of Technology (Poland)

Cezary Ziółkowski, Military University of Technology (Poland)

Andrzej Żyluk, Technical Institute of Air Forces (Poland)

Session Chairs

1 Plenary 1

Andrzej P. Dobrowolski, Military University of Technology (Poland)

2 Plenary 2

Piotr Kaniewski, Military University of Technology (Poland)

3 Image Recognition 1

Zbigniew Bielecki, Military University of Technology (Poland)

Jacek Jakubowski, Military University of Technology (Poland)

4 Radioelectronic Recognition

Ryszard J. Katulski, Gdansk University of Technology (Poland)

Jerzy Kopatka, Military University of Technology (Poland)

5 Radar Technologies

Krzysztof S. Kulpa, Warsaw University of Technology (Poland)

Jerzy Pietrasiński, Military University of Technology (Poland)

6 Jamming and Defence

Piotr Gajewski, Military University of Technology (Poland)

Marek Suchański, Military Communications Institute (Poland)

$7 \quad$ Image Recognition 2

Krzysztof Kopczyński, Military University of Technology (Poland)

Piotr Kaniewski, Military University of Technology (Poland)

8 Information Security

Zbigniew Piotrowski, Military University of Technology (Poland)

Janusz Furtak, Military University of Technology (Poland)

9 High Energy Pulses

Marian Wnuk, Military University of Technology (Poland)

Roman Kubacki, Military University of Technology (Poland) 
10 Sensor Networks

Jerzy Kopatka, Military University of Technology (Poland)

Waldemar Susek, Military University of Technology (Poland)

11 Localization and Bearing

Bogusław Smólski, Military University of Technology (Poland)

Bronisław Stec, Military University of Technology (Poland)

12 Signal Processing

Zbigniew Piotrowski, Military University of Technology (Poland)

Cezary Ziółkowski, Military University of Technology (Poland)

13 Poster Session

Mateusz Pasternak, Military University of Technology (Poland)

Piotr Samczyński, Warsaw University of Technology (Poland) 
Proc. of SPIE Vol. 11055 1105501-12

Downloaded From: https://www.spiedigitallibrary.org/conference-proceedings-of-spie on 26 Apr 2023 Terms of Use: https://www.spiedigitallibrary.org/terms-of-use 


\section{Introduction}

Increasingly, the modern world has become more and more dependent on electronics and information. The use of radio-electronic systems in communication, navigation, reconnaissance, and electronic warfare have become widespread.

The issues of both reconnaissance and electronic warfare are becoming increasingly important. This area of human activity requires monitoring for broadly understood security purposes, and, if necessary, the ability to retake control over the technology or prevent it from being disrupted. As a result, these activities, which until recently have been the exclusive domain of armed forces, are now also beginning to play a significant role in the activity of other state services and governmental bodies.

The issues presented at the Reconnaissance and Electronic Warfare Systems (CREWS) conference are priorities for the Polish Armed Forces (as well as other state services) emphasizing the fact that this conference was organized under the auspices of the Chief of General Staff. The scope of issues discussed during the conference has been gradually expanding. The topics of this conference included: issues related to the current state, needs, and requirements in the field of reconnaissance and electronic warfare; image and optoelectronic reconnaissance; satellite recognition; the use of unmanned aerial vehicles in reconnaissance and electronic warfare; information security; coordination of activities on a national scale; techniques and methods of electronic warfare; and data processing in reconnaissance and electronic warfare systems.

In addition, the conference was supported by the scientific patronage of the Electronics and Telecommunications Committee of the Polish Academy of Sciences. The group of institutions interested in active participation in the conference is systematically expanding, which favors the integration of the environment dealing with the issues of reconnaissance and electronic warfare.

This year's edition of the CREWS conference was an opportunity to exchange the knowledge and experience between users, producers, and scientists involved in the use and construction of reconnaissance and electronic warfare systems. The conference was also a place for bilateral talks and networking.

Piotr Kaniewski 
Proc. of SPIE Vol. 11055 1105501-14

Downloaded From: https://www.spiedigitallibrary.org/conference-proceedings-of-spie on 26 Apr 2023 Terms of Use: https://www.spiedigitallibrary.org/terms-of-use 